\title{
M
}

MONTANA

STATE UNIVERSTTY

LIBRARY

\section{Ergonomics Service Learning Project: Implementing an Alternative Educational Method in an Industrial Engineering Undergraduate Ergonomics Course}

\section{Authors: Lenore Page and Laura M. Stanley}

This is the peer reviewed version of the following article: Page, Lenore T., and Laura M. Stanley. "Ergonomics Service Learning Project: Implementing an Alternative Educational Method in an Industrial Engineering Undergraduate Ergonomics Course." Human Factors and Ergonomics in Manufacturing \& Service Industries 24, no. 5 (2014): 544-556, which has been published in final form at http://dx.doi.org/10.1002/hfm.20544. This article may be used for non-commercial purposes in accordance With Wiley Terms and Conditions for self-archiving. This is a postprint of an article that originally appeared in Human Factors and Ergonomics in Manufacturing \& Service Industries on July 8, 2014. http://onlinelibrary.wiley.com/journal/10.1002/(ISSN)1520-6564

Page, Lenore T., and Laura M. Stanley. "Ergonomics Service Learning Project: Implementing an Alternative Educational Method in an Industrial Engineering Undergraduate Ergonomics Course." Human Factors and Ergonomics in Manufacturing \& Service Industries 24, no. 5 (2014): 544-556. http://dx.doi.org/10.1002/hfm.20544

Made available through Montana State University's ScholarWorks scholarworks.montana.edu 


\title{
Ergonomics Service Learning Project: Implementing an Alternative Educational Method in an Industrial Engineering Undergraduate Ergonomics Course
}

\author{
Lenore T. Page and Laura M. Stanley \\ Mechanical and Industrial Engineering Department, Montana State University, Bozeman, Montana
}

\begin{abstract}
The Accreditation Board for Engineering and Technology (ABET) and the Engineer of 2020, an engineering education initiative, have recommended that engineering students be provided with opportunities to participate in real-world projects in order to supply them with the skills they will need in the workplace. Service learning is a pedagogical approach where students apply skills they learn in a classroom to a real-world problem identified by a community organization. In 2009, a service learning project was introduced in an undergraduate Ergonomics Industrial Engineering course composed of engineering and non-engineering students at Montana State University (MSU). Its integration and development in the existing course required creating a detailed project description and finding a partner organization. Students worked with clients or staff at the partner organization in order to develop ergonomic solutions for workplace health and safety issues and manufacturing productivity. At the end-of-semester presentations, the community partners, instructor and other students assessed each solution's effectiveness. These assessments found that students, compared to the partner's feedback, undervalued their prototypes with regard to how they improved worker and process efficiency, and they overvalued their solution's creativity, cost and implementation feasibility. In addition, the service learning course's technical and professional skills ranked above the average ABET course outcomes of
\end{abstract}


MSU's Industrial Engineering fall courses. This demonstrates how the service learning project and the intended goals from ABET and Engineer 2020 come together-service learning exposes students to real-world situations that better prepare and inform them of the skills that will be needed after graduation.

Keywords: Service learning; Industrial Engineering; Ergonomics; Human factors; Education

\section{INTRODUCTION}

Accredited undergraduate Industrial Engineering (IE) programs aim to produce graduates with the skills to design, develop, implement and improve systems for people, materials, information, equipment and energy (Engineering Accreditation Commission, 2011). To achieve this result various instructional methods are used. Published ergonomics and human factors instructional resources include: in-class exercises (Stone \& Moroney, 1998), demonstrations (Resnick, 2008; Stone, 2002; Stone \& Moroney, 1998), field trips (Liu et al., 2005; Stone \& Moroney, 1998), guest lectures (Liu et al., 2005), laboratory sections (Jones, 1999; Liu et al., 2005), simulation (Werner \& Finkelmeyer, 2002), interactive learning experiences (Werner \& Finkelmeyer, 2002), case studies (Stone \& Moroney, 1998, Dyck, 2009) and projects (Jones, 1999; Dyck, 2007). These published methods convey ergonomic principles and tools useful to learning about ergonomics yet there are few published pedagogies that include developing and implementing solutions outside of the classroom. The research about real-world projects and ergonomics is sparse. Klatsky (2000) had students propose ergonomic solutions for issues in elder care facilities. Sierra, Benne and Fisk (2002) described an ergonomic psychology course in which students applied the human factors knowledge they learned in the class to a real-world 
project at a zoo. In the past two years Stanley has contributed two articles about using service learning projects in an IE Ergonomics course (Stanley \& Hoyt, 2011; Stanley, Page \& Plumb, 2010). Service learning (S-L) is a method of teaching where students apply skills they learn in a course to a community organization (educational institutions, non-profit or tax-exempt organizations) that has identified a needed service (Oakes, 2004). S-L is a pedagogical approach that can bridge the gulf of execution between ergonomics knowledge and successful ergonomic solutions.

Engineering curricula are among the primary means of preparing IE graduates for the workplace. The Engineer of 2020, an initiative conducted by the National Academy of Engineering's Committee on Engineering Education, recommended innovation and experimentation in the curriculum, use of pedagogical approaches that motivate undergraduate students, facilitation of lifelong learning and introduction to interdisciplinary learning (National Research Council, 2005). The Engineer of 2020 recommendations complement the IE program goals of the Accreditation Board for Engineering and Technology (ABET). The Committee on Engineering Education noted that connecting courses to real-world problems demonstrates the social relevance of engineering and provides an early introduction to core engineering principles, which are designing, building and testing. Service learning situates students outside the classroom where not only their technical skills are improved but their professional skills are further developed (Shuman, Besterfield-Sacre \& McGourty, 2005).

Service learning explicitly requires that classroom-acquired skills be applied to real-world problems (Oakes, 2004). This is an example of a pedagogy that exposes students to real-world problems and the social context of those problems. The pros of using S-L are that it complements coursework, prepares students for practice, exposes students to multidisciplinary teams, is an 
alternate learning environment and improves retention if instituted earlier in undergraduate courses. The cons mainly involve instructor time such as that required to change the course structure to deal with the real-world project and issues that come up while students are working on the S-L project. The benefits of S-L capture the ABET and Engineer of 2020 goals of improved real-world performance of engineering graduates.

ABET professional skills can also be more easily taught and assessed in the real-world context. Shuman, Besterfield-Sacre and McGourty (2005) believe that professional skills "enable" engineering graduates to become innovative problem solvers. Within the group of professional skills, they differentiate between process skills and awareness skills. Process skills involve "communication, teamwork, and the ability to recognize and resolve ethical dilemmas." Students develop processes to address these areas. Awareness skills involve "understanding the impact of global and social factors, knowledge of contemporary issues, and the ability to do lifelong learning." Students learn to apply this understanding in their problem-solving process (Shuman et al., 2005). These skills can be taught through teamwork, written and oral communication, team training, real projects for real clients, and S-L projects in a senior capstone design or virtual-reality environment. No one assessment method has been able to capture the acquisition of professional skills because the outcome definitions are harder to evaluate than the technical skill outcomes. Ideally, Shuman et al. (2005) mention periodic assessment over the entirety of a student's time in the engineering program may give comprehensive assessments that more accurately reflect the ABET outcome acquisition. Self-ratings and reflections force students to think of themselves and about their learning process and are a relatively quick assessment method. Team project effectiveness is typically assessed with a scoring rubric. 
It is important to differentiate that the approach to service learning of "doing with" a community partner is different than "doing for" a community partner (Ward \& Wolf-Wendel, 2000) and how this is reflected in S-L project research. Student outcomes and perspectives are typically measured in S-L project assessments but community organization outcomes and perspectives are not. This study is unique as the assessments include feedback about the proposed project solutions from the partner organization's staff members and clients.

This paper describes the incorporation of S-L into the ergonomics and human factors engineering course in the IE program at Montana State University (MSU). First, it describes how the existing course structure was modified to include the S-L project. Then the process of starting the project with the partner organization and delivering the S-L project to students is explained. Students and members of the organizations gave feedback about the projects, and students gave feedback about the ABET outcomes and their experiences, which improved subsequent course delivery. The paper concludes with a discussion of the assessments and the S-L project's educational value as well as suggested S-L improvements.

\section{METHOD}

\subsection{Changing the Course to a Service Learning Course}

The ergonomics class evaluation structure was initially composed of assignments, exams and daily quizzes to demonstrate course knowledge. Approximately 10 to 16 students take the course each year; most of them are undergraduates in IE while some are undergraduates from the department of Health and Human Development, and some are graduate students from other engineering disciplines. The class meets two times per week for 75 -minute sessions. One professor and one graduate teaching assistant teach the course. This course was the only 
designated Industrial Engineering S-L course at MSU (designation received in Fall 2010) and is one of two S-L courses in the College of Engineering. There were only 13 such designated courses in the whole of MSU's 2011-2012 course offerings. The course is offered each fall semester and the S-L project has been part of the course since Fall 2009.

Changes to the existing course modified the evaluation structure and lecture topic order. The evaluation structure changed to accommodate the S-L project in the course curriculum by reducing the number and weight of assignments and exams. The S-L project comprised nearly half of the final course grade in order to reflect (1) the time and effort students were expected to spend on the project and (2) the demonstration of an applied understanding of the course's ergonomics principles. It was anticipated that the time spent on the project would increase as the semester progressed. Thus the few remaining assignments were front-loaded in the course both to build skills applicable to the project and to balance the student workload for the semester. The number of exams remained the same; however, their weighting decreased. The lecture material was organized to stay ahead of student needs in the S-L project's process. In this case, providing approaches to identifying ergonomic problems was completed before the initial meeting with the partner organization. The initial site visit was done as a group and was scheduled during one class period (75minutes). The ergonomic methods of evaluating work tasks and the economic justification of solutions that address workers' health and safety were also provided early in the course to prepare students for the project demands.

A matching partner organization was chosen prior to the semester based on fit with the ergonomic course objectives and the partner organization's needs. Students worked with clients or staff at the partner organization in order to develop solutions for workplace health and safety issues and manufacturing productivity. The partner organization in the Fall 2009 and Fall 2010 
semesters was Reach Inc., a non-profit organization that provides vocational support to people with disabilities. This organization was found through the AbilityONE Network Design Challenge (National Industries for the Severely Handicapped, n.d.). Students worked with Reach clients who performed manual assembly tasks for local manufacturing companies. The Fall 2011 organization was MSU's Safety and Risk Management department, which provides programs for university employees' safety. This organization was chosen from previous instructor contact regarding ergonomic issues. Students worked with MSU employees who performed manual labor tasks to prepare food for campus restaurants, clean student dormitories and move bedroom furniture in and out of dormitories.

The instructor determined the composition of the student groups balancing for skill set. For example a group of three may have included one undergraduate IE, one undergraduate in health and human development and one graduate civil engineering student.

The S-L project description provided to students at the start of the semester included the requirement that they produce a deliverable and achieve certain milestones. It was expected that students would deliver a working prototype to Reach, a material list and the associated costs of a proposed prototype to MSU Safety and Risk Management.

Members (clients, managers and employees) of the partner organization were asked to attend the student presentations and at the end of the semester to provide feedback on project effectiveness.

\subsection{Assessments}

The assessment tools varied from year to year and thus were not comparable across all years. Assessment tools used for student learning outcomes changed as the course progressed in order 
to improve understanding of the outcomes and introduce the Mechanical \& Industrial Engineering Department ABET assessments for engineering students (started Fall 2010). Project effectiveness, project ABET outcomes, course ABET outcomes and service-learning reflections are discussed in the following sub-sections.

\subsubsection{Project Effectiveness}

Students (Fall 2009 and 2010) and members of the community partner who attended the final presentations (Fall 2009, 2010 and 2011) evaluated the projects using seven criteria for which the possible responses were: excellent, good and needs improvement (Table 1). The S-L project prototypes were evaluated for solution creativity, cost feasibility, implementation feasibility, potential increase for process efficiency, promotion of worker efficiency, improvement of worker health and safety, and increase of worker satisfaction. These seven criteria were based on the ergonomics goals to optimize human well-being and overall system performance (Kroemer, 2008). Results from the project effectiveness evaluations were used to provide feedback to the students at the presentations as well as inform course modifications.

\subsubsection{Project ABET Outcomes}

All students (engineering and non-engineering) in the Fall 2009 course completed a Project ABET assessment based on the applicable ABET outcomes from (a) through (k) (Engineering Accreditation Commission, 2008). The survey in Fall 2009 used statements about the project and multiple ABET outcomes were inferred from the statements (Stanley, Page \& Plumb, 2010).

\subsubsection{Course ABET Outcomes}


The Fall 2010 and Fall 2011 Course ABET outcome assessment tool was different from the Project ABET assessment. The Course ABET outcome was implemented across all of the IE courses in the Mechanical and Industrial Engineering Department at MSU and only engineering students were to respond in one of four ways: strongly disagree, disagree, agree, or strongly agree to the course's applicable ABET outcomes (a) through (k) (Table 2) (Stanley \& Hoyt, 2011). Not all ABET outcomes apply for each IE course and in Table 2, the specific applicable ABET outcomes for the S-L course are noted. The other IE courses will select their respective applicable ABET outcomes. Thus the professional ABET skills were divided into process (d, $\mathrm{f}$,

and g), awareness (h, i, and j) and technical skills (a, b, c, e, and k) as per Schuman, BesterfieldSacre and McGourty (2005) in order to compare the skills to other IE courses. The engineering student responses were averaged for the three skill categories and the S-L course then compared to all of the IE course averages (freshman- to senior-level classes).

\subsubsection{Service Learning Reflections}

In Fall 2010 structured student reflections were completed in three journal activities where students responded to open-ended questions (Table 3) (Stanley \& Hoyt, 2011). The questions asked students to connect their previous experiences to the current S-L project experiences as well as explain their understanding of the context they worked in with the S-L experience. These comments later informed course modifications.

\section{RESULTS}

\subsection{Service Learning Modifications}


Two avenues to find a partner organization were used for this course. The first partner organization was found through the AbilityONE Network Design Challenge. The second was the MSU Health and Safety Program. Each of these resources required a small effort on the part of the instructor to contact the organization and suss out the suitability of the match with the ergonomic course content. After speaking with the potential partner and learning of their expectations, it was important for the course instructor to determine what students could realistically deliver within a timeframe of just under a semester. Discussions with the community partner created an understanding for both parties as far as the project's scope and expected deliverable(s).

During the presentations in Fall 2009, Reach staff pointed out both the usefulness of having a working prototype as well as the infeasibility of the design budgets for some of the prototypes. While cost was a prototype constraint mentioned in the S-L project description, the reality of the need was not well perceived by the students. From Fall 2010 onward, greater emphasis was placed on meeting the partner organization's budget in the project description. Also in Fall 2010 project groups were required to have a tangible, working prototype for Reach. In Fall 2011 with MSU's Health and Safety Program, the required deliverable(s) varied according to the problem addressed. Some of the problems presented could not have a prototype but were required to have cost and drawings of a prototype.

In the feedback about the course structure and S-L project in Fall 2009 students asked for clarification of the project deliverable and more milestones to help them stay on task throughout the semester. In order for students to better understand what was expected of them they received the project description and a project grading rubric. The expected deliverable was expanded upon in the project description and was given to students along with the project's grading rubric before 
the initial client meeting in Fall 2010. In Fall 2011 the project description included four milestones set to ensure the student groups progressed with their project throughout the semester and so that students could receive early feedback about their problem definition and proposed methodology. Students were to define the problem (by the fifth week of class), propose their solution methodology (eighth week), submit a final report (last week) and present their solution in class with the community partners present (last week).

Throughout the semester questions arose from the students about how to work with the community partners and how to work within their project groups. Students typically sought the instructor's advice after class.

\subsection{Assessments}

\subsubsection{Project Effectiveness}

The project effectiveness of both Reach projects, Fall 2009 and 2010, demonstrated the differences between students' perceptions of the projects' effectiveness and the community partner's perceptions. Student evaluations (Fall 2009) of creativity and cost feasibility were higher than the partners' perceptions, with the partner perceiving higher potential to increase process and worker efficiency, as well as improving worker health and safety and increasing worker satisfaction (Figure 1) (Stanley, Page \& Plumb, 2010). Stanley and Hoyt (2011) found similar results in Fall 2010 but in that S-L project, students perceived higher implementation feasibility than Reach members.

In Fall 2011, only MSU Health and Safety Program members provided an evaluation (Figure 2). The partner organization members perceived the solutions as near to excellent in the areas of feasibility of implementation, improving worker health and safety, and increasing worker 
satisfaction. Cost feasibility and creativity were generally responded to as "good" and there was more variation around "good" in regard to both process efficiency and worker efficiency.

\subsubsection{Project ABET Outcomes}

The ABET survey in Fall 2009 indicated that $89 \%$ of students agreed they improved their technical (hard) skills and 73\% agreed they improved their professional (soft) skills (Stanley, Page \& Plumb, 2010). Engineering and non-engineering students responded to these questions.

\subsubsection{Course ABET Outcomes}

A comparison of the S-L course with the other courses in the IE program in Fall 2010 (10 courses) and Fall 2011 (9 courses) shows the mean ABET scores for the S-L course were close to "agree" and consistently in the top three for professional skills of process and awareness (Table 4). The mean S-L technical score was above the mean for IE courses, also "agree" but not quite as high as the professional skills (fifth in 2010 and second in 2011). While there were 11 respondents in the $2010 \mathrm{~S}-\mathrm{L}$ course, there were just 3 respondents (three engineering students) in the Fall 2011 S-L course, so only descriptive statistics were used for the comparison. The other IE fall courses had a range of 10 to 42 engineering student respondents.

The composition of engineering students $(3,10,11,11,11,12,12,15,15,15,17,18,18,21$, $21,23,24,62$, and 65 ) in each of the IE fall courses was explored by sex, ethnicity, engineering major, classification (freshman, sophomore, junior, senior and other) and cumulative grade point average (CGPA) in order to characterize S-L students compared to students in the other IE courses. The composition of engineering students from the IE fall courses show that the S-L course had similar proportions to the other courses in 2010 regarding sex, ethnicity and 
engineering major (Figure 3). The 2010 differences appeared in higher proportions of nonbachelor students (Figure 4), lower proportions of seniors (Figure 4) and higher proportion of students with CGPAs between 2 and 3 than 3 and 4 (Figure 5). The 2011 S-L course varied from other IE courses with a lower proportion of males (Figure 6), a higher proportion of juniors (Figure 7), and a higher frequency of students with CGPAs between 2 and 3 than 3 and 4 (Figure 8).

\subsubsection{Service Learning Reflections}

The responses to the structured questions revealed the students perceived the societal context of engineering and the engineer's primary duty to the public good (Stanley \& Hoyt, 2011). Students experienced satisfaction working on the Fall 2010 Reach project in that it allowed them to both design and be creative with a view to helping others. They also felt they acquired the communication skills they needed to work with different types of people in the S-L project.

\section{DISCUSSION}

At MSU and within ergonomics undergraduate IE education, service learning is a unique approach to teaching ergonomics. The course studied was the only IE course at MSU with an S$\mathrm{L}$ designation. There are few studies that promote the use of S-L projects in ergonomics and human factors courses outside of Stanley's previous publications for IE. Sierra, Benne and Fisk (2002) and Klatsky (2000) reported on student assessment measures but did not include community partners' perspective as was done with this study. Most of the S-L project improvements identified in this study were based on feedback (student and community partner) from the assessment tools along with other observations and informal feedback. 
The student evaluations of the Reach project's efficiencies were different from Reach's evaluations of the same projects. Students gave lower scores to the process and worker efficiency goals than the Reach staff and clients. The low scores by students for Fall 2009 and Fall 2010 could be due to not understanding what efficiency meant to Reach. This may be an indication that IE classes about productivity and efficiency have failed to include discussions about populations other than typical, able-bodied manufacturing workers and the students were unable to adjust their expectations. These underlying attitudes could explain the disparity of efficiency scores and most likely contributed to students grading the projects lower in efficiency.

Another discrepancy between the students and Reach was related to creativity, cost effectiveness and feasibility of implementation, all of which may relate to the amount of realworld experience students have. The students graded themselves higher than Reach staff in solution creativity, cost of solution and solution implementation. The higher creativity scores for prototype solutions could be due to the novelty of the S-L project. This was a new experience for the students and they reported in Fall 2010 journal reflections that this project allowed them to be creative. A majority of students in Sierra, Benne and Fisk (2002) also reported that their project was "creatively challenging." Exposure to other S-L projects and real-world situations would likely adjust a student's recognition of cost and implementation feasibility more closely to the community partner's views. The score differences could also be due to not communicating the cost effectiveness in a meaningful way to the community partner during the presentations. Nonetheless, these discrepancies all point to the intended purpose of an S-L project, which is to expose students to real-world situations that will better prepare them for the workplace after graduation. 
Comparing the S-L course to other IE courses through the mean ABET outcomes showed the S-L course was above the IE program average in all skills and was in the top three for process and awareness skills. Even after comparing student characteristics, the S-L course composition was similar to the other IE courses offered the same semester showing few differences that would indicate the engineering students in the S-L course differed from students in the other IE courses. The ABET scores indicate that implementing the S-L project did not detract from ABET outcomes when compared to the other courses, which could allay any concerns about affecting student educational experiences during S-L implementation.

Primarily in Fall 2009, students requested more structure in the S-L project. This need arose in discussions with students and in project evaluations. This makes sense because real-world problems tend to be more difficult to define than classroom-assigned problems and the complexity is greater. Students are learning how to apply ergonomic theory and how to include real-world constraints in their solutions. To meet this student need, the instructor added detail to the project description, clarified the expected deliverables and distributed the project's grading rubric at the start of the Fall 2010 and 2011 courses. The explicit project structure allowed students to determine if they were meeting the educational reporting requirements of the course while still being responsible for the client's needs.

The partner organization identified poorly met needs in the project effectiveness assessments. Including cost and implementation feasibility in the assessment opened dialogue about the practicality of the proposed solutions. Prototypes were rated by organizations as "good" to "excellent" but the key issue, which students had trouble achieving, was meeting the cost constraints. The prototypes put to use immediately at Reach were ones that met the needs of the organization and were easy to implement. This feedback led to emphasizing costs and 
implementation feasibility to students through the project descriptions (i.e., telling students to ask the partner what the budget is) and in class project discussions.

Instructor effort to implement the S-L project within an existing course required changing the evaluation structure, finding a partner organization, creating a detailed project description and fielding project management questions from students. Of the four tasks, finding a partner organization and fielding student questions most likely involves the most instructor effort. Realizing that a partner organization is available at most university campuses can reduce the effort required to find an organization. Instructors may find that students have questions about professional skills after working in the real world, such as how to work with the partner organization's members.

Recommended course improvements relate to student needs. The idea of a one credit recitation section, run by the graduate teaching assistant, would avail expertise for design reviews and answers to questions about how to work with the community partners. In addition, this section could be used to help students address solution and implementation costs. Offering some of this recitation time to workshops about managing group dynamics or working in a realworld situation would improve the group experience and client interactions in addition to improving the students' professional skills.

The S-L project moves the IE curriculum and ergonomics education from theory to application—students using classroom skills to design, develop, implement and improve systems for people in real-world situations.

\section{CONCLUSION}


Students used their ergonomics knowledge to solve real-world problems that were illdefined, in some instances, and solutions that were constrained. The Engineer of 2020 objectives are to provide students with opportunities to participate in real-world projects in order to provide them with the skills they will need in the workplace. ABET aims to have IE graduates that possess the skills to design, develop, implement and improve systems. Both of those objectives are met by involving the community partner in the process and measuring the community partner's perceived effectiveness of the solutions in addition to student responses.

The partner organization's involvement shifts the assignment from a theoretical exercise to an applied S-L project. S-L has been perceived as time intensive for instructors to implement but using the resources to find a partner on campus, or using a design competition website, can reduce the off-campus effort required of the instructor. In addition, the learning experience for students when compared to other IE fall courses showed the technical, process and awareness skills all ranked above the average ABET course outcomes. Service learning is a pedagogy that can fit well within an undergraduate IE human factors and ergonomics course and advance engineering education toward the ABET and Engineer 2020 objectives.

\section{ACKNOWLEDGMENTS}

The authors would like to thank the entire Reach staff, the Montana State University custodial supervisors and staff, and MSU Skinny Kitty Salads staff for their cooperation with this project. Special thanks go to Kathy Rasmussen, the contact development supervisor for Reach, for coordinating the vocational aides and clients involved with the project. We would also like to thank National Industries for the Severely Handicapped for its assistance in identifying REACH. Special thanks also to Laurie Bachar, the Manager of the Occupational Health—Safety \& Risk 
Management Group at Montana State University, for coordinating the MSU employee groups. Additionally, we are very grateful to the Reach vocational aides, Reach clients and MSU employees for their time spent working with the students. 


\section{References}

Dyck, J. L. (2007). Teaching human factors principles through design of an exit sign. Proceedings of the Human Factors and Ergonomics Society 51st Annual Meeting, Maryland. pp. 1168-1170.

Dyck, J. L. (2009). Creative design solutions as a class exercise. Ergonomics in Design: The Quarterly of Human Factors Applications, 17(1), 6-7.

Engineering Accreditation Commission. (2008). Criteria for accrediting engineering programs: Effective for reviews during the 2009-2010 accreditation cycle. Baltimore, Maryland: ABET Inc.

Engineering Accreditation Commission. (2011). Criteria for accrediting engineering programs: Effective for reviews during the 2012-2013 accreditation cycle. Baltimore, Maryland: ABET Inc.

Jones, D. (1999). Hands-on human factors and ergonomics education. Proceedings of the Human Factors and Ergonomics Society 43rd Annual Meeting, Houston, Texas. pp. 535-538.

Klatsky, G. J. (2000). Incorporating service learning in an introductory human factors course. Proceedings of the XIVth Triennial Congress of the International Ergonomics Association 2000 and 44th Annual Meeting of the Human Factors and Ergonomics Society, San Diego, California. pp. 271-274.

Kroemer, K. H. E. (2008). Fitting the human: Introduction to ergonomics (6th ed.). Boca Raton, Florida: CRC Press.

Liu, D., Baskin, A., Greene, F., \& Frederick-Recascino, C. (2005). Designing human factors courses with a human factors mind. Proceedings of the Human Factors and Ergonomics Society 49th Annual Meeting, Orlando, Florida. pp. 783-787. 
National Industries for the Severely Handicapped. (n.d.). AbilityOne network design challenge (formerly the national scholar award for workplace innovation \& design competition). Retrieved 08/20, 2009, from http://www.nish.org/

National Research Council. (2005). Recommendations, educating the engineer of 2020: Adapting engineering education to the new century. Washington, D.C.: The National Academies Press.

Oakes, W. (2004). Service-learning in engineering: A resource guidebook. Providence, Rhode Island: Campus Compact.

Resnick, M. L. (2008). Teaching human factors through popular music: A series of human information processing demonstrations. Proceedings of the Human Factors and Ergonomics Society 52nd Annual Meeting, New York, New York. pp. 629-633.

Schuman, L. J., Besterfield-Sacre, M., \& McGourty, J. (2005). The ABET "professional skills" can they be taught? can they be assessed? Journal of Engineering Education, 94(1), 41-55.

Sierra, E. A., Benne, M., \& Fisk, A. D. (2002). It's A zoo out there: Teaching human factors in a real-world context. Ergonomics in Design: The Quarterly of Human Factors Applications, 10(3), 6-10.

Stanley, L. M., \& Hoyt, T. (2011). A service learning case study for the ergonomics classroom. Proceedings of the Human Factors and Ergonomics Society 55th Annual Meeting, Las Vegas, Nevada. pp. 525-529.

Stanley, L. M., Page, L., \& Hoyt, T. (2010). Designing for the disabled in the engineering classroom. Proceedings of the 40th Annual Frontiers in Education Conference, Washington, D.C. pp. T2D-1-T2D-6. 
Stone, N. (2002). Teaching techniques and demonstrations: Let's not recreate the wheel. Proceedings of the Human Factors and Ergonomics Society 46th Annual Meeting, Baltimore, Maryland. pp. 792.

Stone, N., \& Moroney, W. F. (1998). Teaching undergraduate human factors. Teaching of Psychology, 25(3), 185-189.

Ward, K., \& Wolf-Wendel, L. (2000). Community-centered service learning: Moving from doing for to doing with. American Behavioral Scientist,43(5), 767-780.

Werner, S., \& Finkelmeyer, A. E. (2002). Reusable simulations and interactive learning experiences in human factors education. Proceedings of the Human Factors and Ergonomics Society 46th Annual Meeting, Baltimore, Maryland. pp. 779-782. 
Ergonomics Service Learning Project: Implementing an Alternative Educational Method in an Industrial Engineering Undergraduate Ergonomics Course

Table 1. Questions Used in the Overall Project Effectiveness Evaluation

Please rate performance according to:

Response

Creativity

Cost Feasibility

Feasibility of Implementation

Potential to Increase Process Efficiency

Impact to the worker in terms of promoting efficiency

Excellent

Impact to the worker in terms of health and safety

$2=$ Good,

Impact to the worker in terms of increasing worker satisfaction 
Ergonomics Service Learning Project: Implementing an Alternative Educational Method in an Industrial Engineering Undergraduate Ergonomics Course

Table 2. Service Learning Course Evaluation Based on Applicable ABET Outcomes

\begin{tabular}{|c|c|c|c|c|c|}
\hline \multirow[b]{2}{*}{ ABET Outcome Description } & \multirow{2}{*}{$\begin{array}{l}\text { Applies } \\
\text { to } \text { S-L } \\
\text { Course } \\
\end{array}$} & \multicolumn{2}{|c|}{ Professional Skills } & \multirow{2}{*}{$\begin{array}{l}\text { Technical } \\
\text { Skills }\end{array}$} & \multirow[b]{2}{*}{ Response } \\
\hline & & Process & Awareness & & \\
\hline $\begin{array}{l}\text { a. An ability to apply knowledge of } \\
\text { mathematics, science, and } \\
\text { engineering }\end{array}$ & & & & Yes & \\
\hline $\begin{array}{l}\text { b. An ability to design and conduct } \\
\text { experiments, as well as to } \\
\text { analyze and interpret data }\end{array}$ & & & & Yes & \\
\hline $\begin{array}{l}\text { c. An ability to design a system, } \\
\text { component, or process to meet } \\
\text { desired needs within realistic } \\
\text { constraints such as economic, } \\
\text { environmental, social, political, } \\
\text { ethical, health and safety, } \\
\text { manufacturability, and } \\
\text { sustainability }\end{array}$ & Yes & & & Yes & \\
\hline $\begin{array}{l}\text { d. An ability to function on } \\
\text { multidisciplinary teams } \\
\text { e. An ability to identify, formulate, } \\
\text { and solve engineering problems }\end{array}$ & Yes & Yes & & Yes & $\begin{array}{r}1=\text { Strongly } \\
\text { Disagree }\end{array}$ \\
\hline $\begin{array}{l}\text { f. An understanding of professional } \\
\text { and ethical responsibility }\end{array}$ & Yes & Yes & & & $\begin{array}{l}2=\text { Disagree } \\
3=\text { Agree }\end{array}$ \\
\hline $\begin{array}{l}\text { g. An ability to communicate } \\
\text { effectively. }\end{array}$ & Yes & Yes & & & $4=$ Strongly \\
\hline $\begin{array}{l}\text { h. The broad education necessary to } \\
\text { understand the impact of } \\
\text { engineering solutions in a } \\
\text { global, economic, } \\
\text { environmental, and societal } \\
\text { context }\end{array}$ & Yes & & Yes & & \\
\hline $\begin{array}{l}\text { *i. A recognition of the need for, } \\
\text { and an ability to engage in, life- } \\
\text { long learning }\end{array}$ & Yes & & Yes & & \\
\hline $\begin{array}{l}\text { j. A knowledge of contemporary } \\
\text { issues }\end{array}$ & Yes & & Yes & & \\
\hline $\begin{array}{l}\text { k. An ability to use the } \\
\text { techniques, skills, and modern } \\
\text { engineering tools necessary for } \\
\text { engineering practice }\end{array}$ & & & & Yes & \\
\hline
\end{tabular}


Ergonomics Service Learning Project: Implementing an Alternative Educational Method in an Industrial Engineering Undergraduate Ergonomics Course

Table 3. Structured Student Reflection Questions

Journal

Activity

Questions requiring at least $\mathbf{1 0 0}$-word responses

Activity \#1 What has surprised you about your disabled client?

What past experiences have you been able to draw on to complete this project successfully?

What are the strengths you bring to a team project such as this?

Activity \#2 What has been the most difficult part of designing an assistive aid?

What has been the most difficult part about working on a team for this project?

What are your challenges (or weaknesses) that you could improve on for future similar projects?

Activity \#3 What have you learned during this project that you can apply to other areas of your life, either in school or out?

Has this project changed the way you think about engineering as a profession?

Now that you've completed the project, what could you have done differently to

bring the project to a better outcome? What could your team have done differently? 
Ergonomics Service Learning Project: Implementing an Alternative Educational Method in an Industrial Engineering Undergraduate Ergonomics Course

Table 4. ABET Mean Skill Group Scores for all Industrial Engineering Courses in Fall 2010 and Fall 2011

\begin{tabular}{|c|c|c|c|c|c|c|c|c|c|c|c|}
\hline & $\begin{array}{r}\text { Techr } \\
\text { Mea }\end{array}$ & $\begin{array}{l}\text { Skill } \\
\text { ore }\end{array}$ & & & $\begin{array}{l}\text { Proc } \\
\text { Mea }\end{array}$ & $\begin{array}{l}\text { Skill } \\
\text { core }\end{array}$ & & & $\begin{array}{r}\text { Awar } \\
\text { Me }\end{array}$ & $\begin{array}{l}\text { S Sk } \\
\text { core }\end{array}$ & \\
\hline Course & 2010 & & 2011 & & 2010 & & 2011 & & 2010 & & 2011 \\
\hline & 3.39 & & 3.56 & & 3.15 & S-L & 3.44 & & 3.36 & S-L & 3.83 \\
\hline & 3.34 & S-L & 3.50 & S-L & 3.06 & & 3.17 & & 3.27 & & 3.36 \\
\hline & 3.29 & & 3.46 & & 3.05 & & 3.16 & S-L & 3.10 & & 3.14 \\
\hline & 3.20 & & 3.38 & & 3.02 & & 3.15 & & 3.03 & & 3.11 \\
\hline S-L & 3.19 & & 3.12 & & 2.95 & & 2.97 & & 2.95 & & 3.05 \\
\hline & 3.08 & & 3.02 & & 2.93 & & 2.92 & & 2.88 & & 2.98 \\
\hline & 3.02 & & 2.95 & & 2.90 & & 2.91 & & 2.87 & & 2.93 \\
\hline & 2.86 & & 2.94 & & 2.67 & & 2.02 & & 2.86 & & 2.40 \\
\hline & 2.83 & & 2.19 & & 2.50 & & & & 2.77 & & \\
\hline & 2.59 & & & & 2.28 & & & & 2.58 & & \\
\hline$M$ & 3.08 & & 3.12 & & 2.85 & & 2.97 & & 2.97 & & 3.10 \\
\hline$S D$ & 0.26 & & 0.43 & & 0.28 & & 0.42 & & 0.23 & & 0.40 \\
\hline
\end{tabular}


Ergonomics Service Learning Project: Implementing an Alternative Educational Method in an Industrial Engineering Undergraduate Ergonomics Course

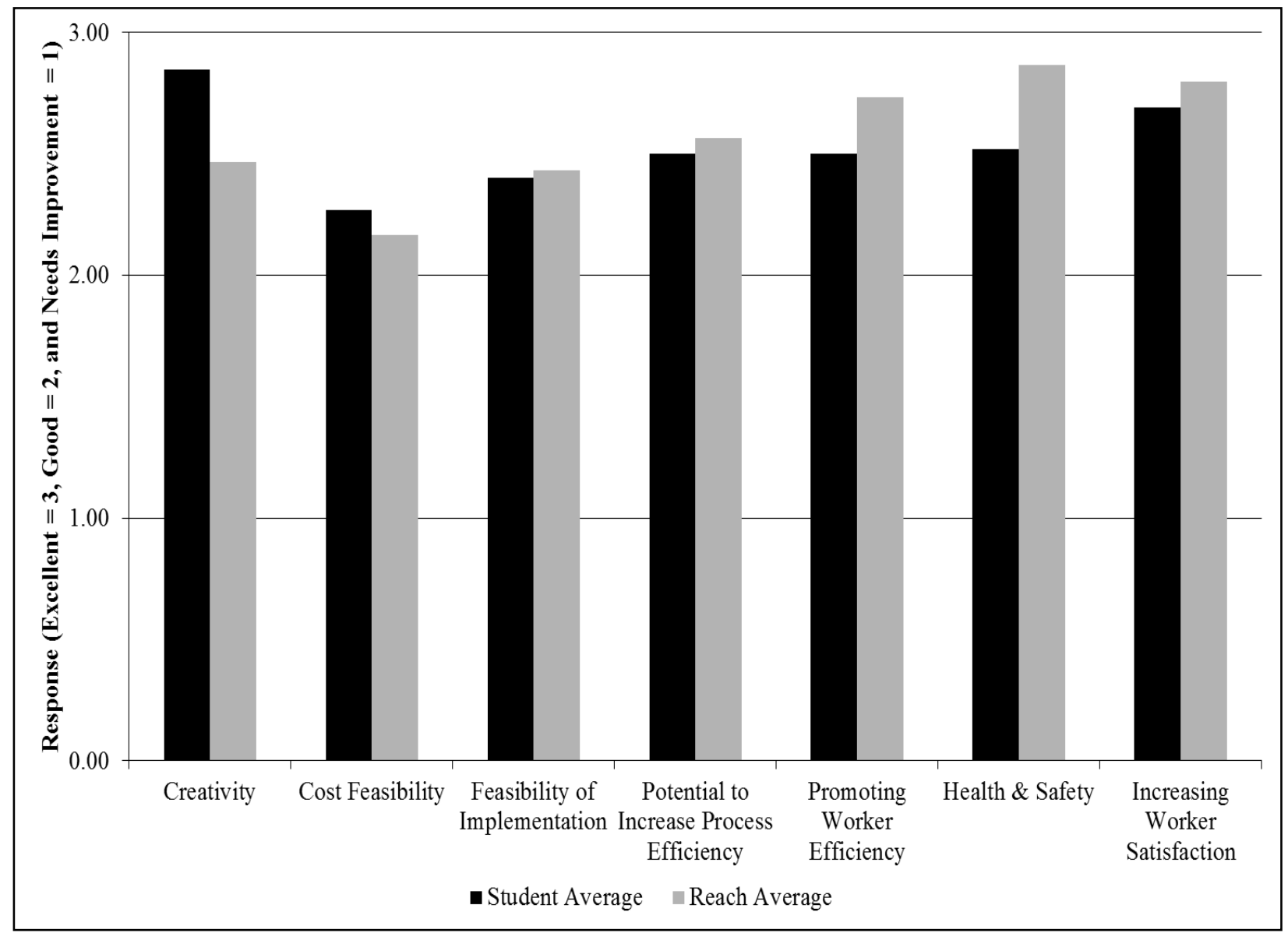

Figure 1. Fall 2009 S-L Project Effectiveness Evaluation Comparing Student and REACH Members 
Ergonomics Service Learning Project: Implementing an Alternative Educational Method in an Industrial Engineering Undergraduate Ergonomics Course

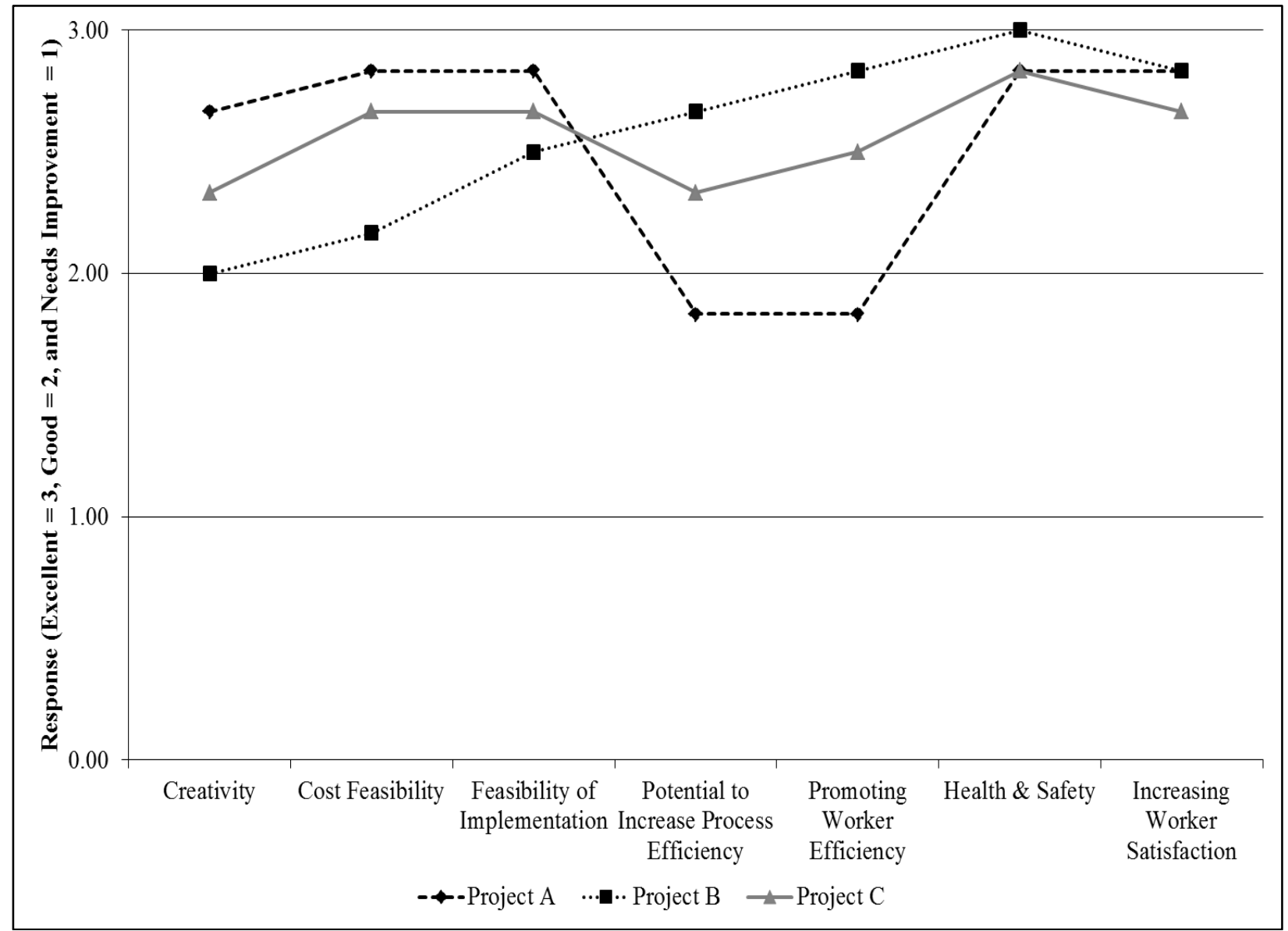

Figure 2. Fall 2011 S-L Project Effectiveness Evaluation MSU Health and Safety Members 
Ergonomics Service Learning Project: Implementing an Alternative Educational Method in an Industrial Engineering Undergraduate Ergonomics Course

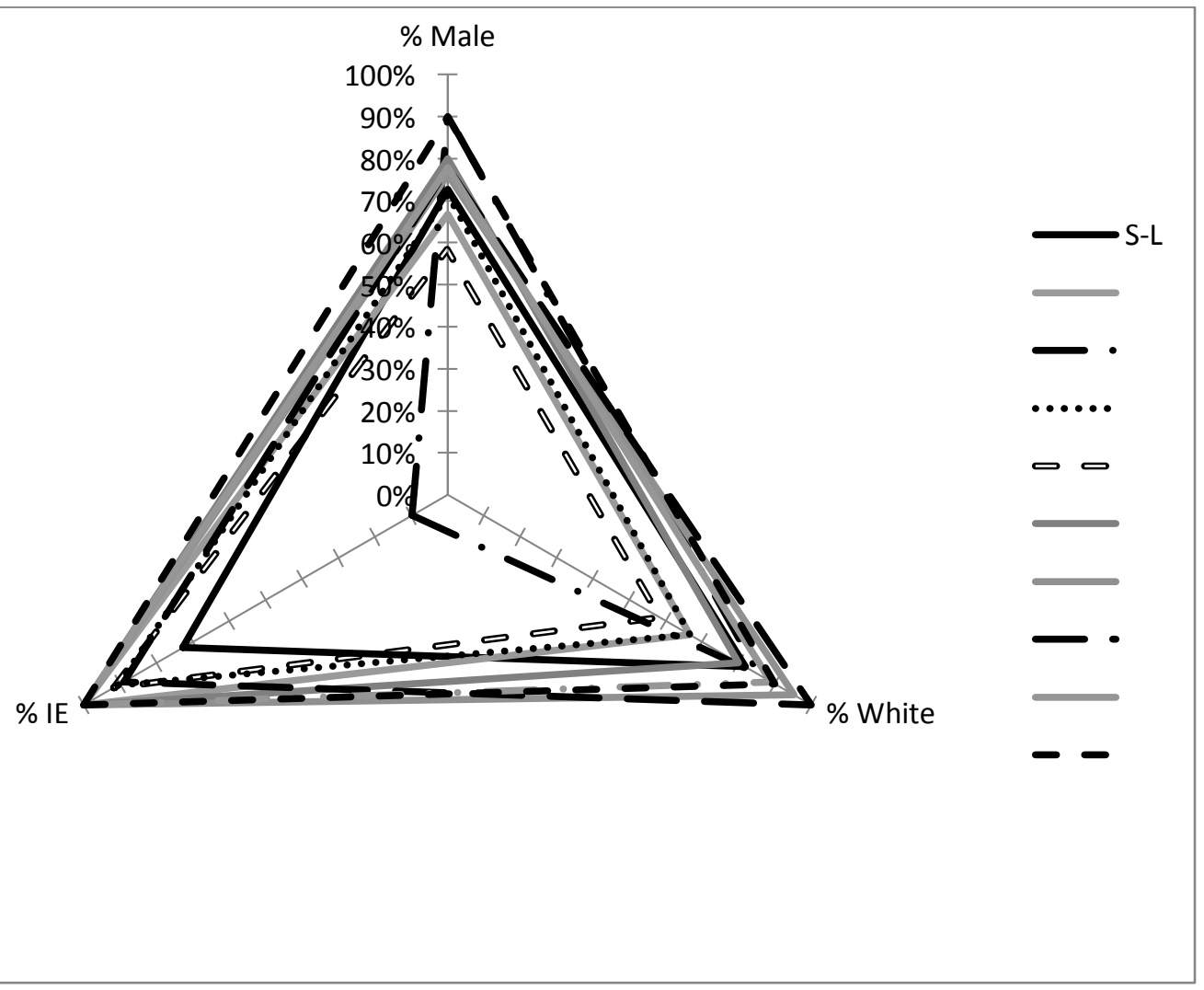

Figure 3. Fall 2010 Industrial Engineering Courses Showing the Proportion of Students in Each Course by Sex, Ethnicity and Engineering Major 
Ergonomics Service Learning Project: Implementing an Alternative Educational Method in an Industrial Engineering Undergraduate Ergonomics Course

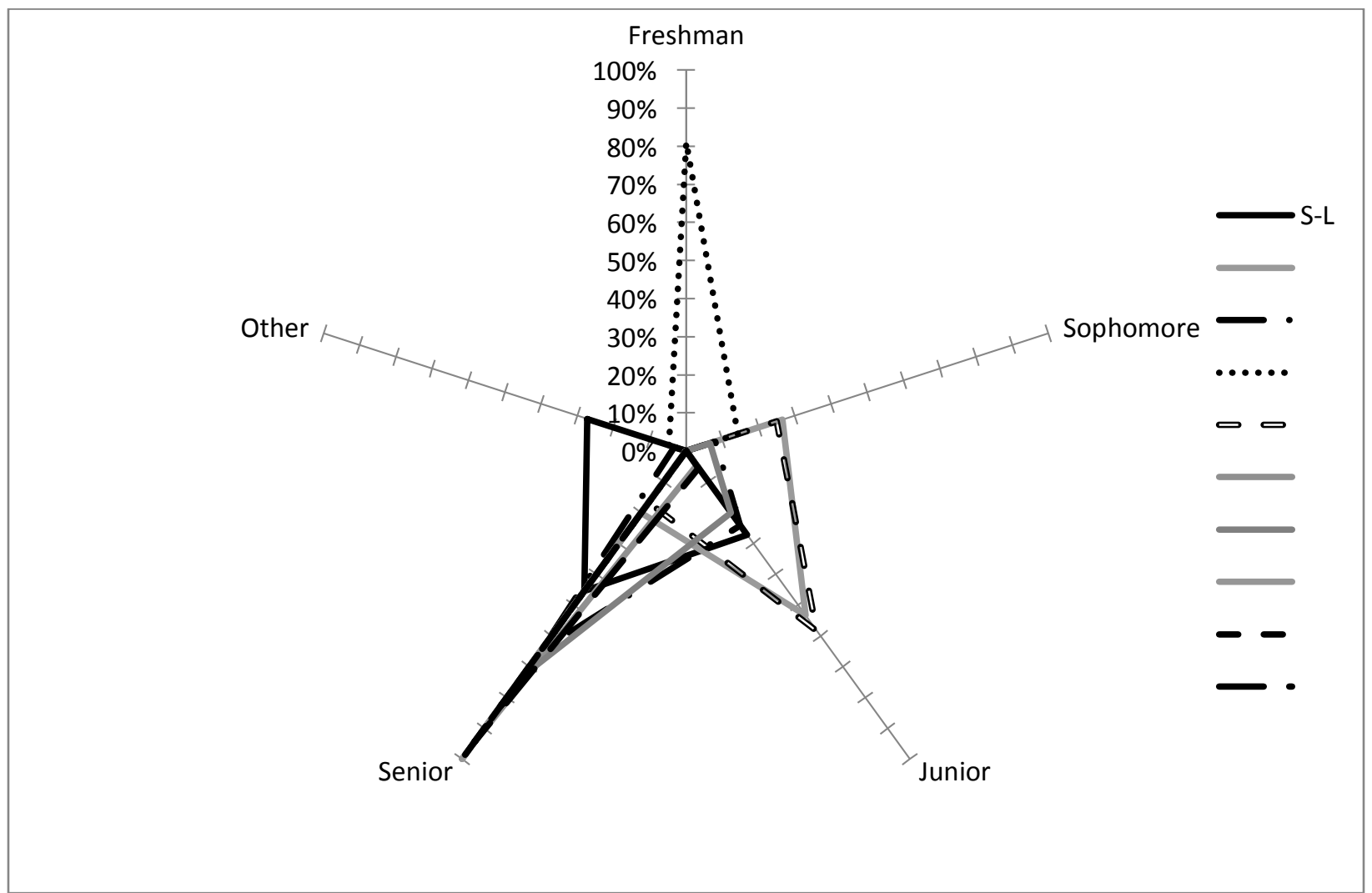

Figure 4. Fall 2010 Industrial Engineering Courses Showing the Proportion of Engineering Students in Each Course by Freshman, Sophomore, Junior, Senior and Other (Graduate or Post-Baccalaureate) 
Ergonomics Service Learning Project: Implementing an Alternative Educational Method in an Industrial Engineering Undergraduate Ergonomics Course

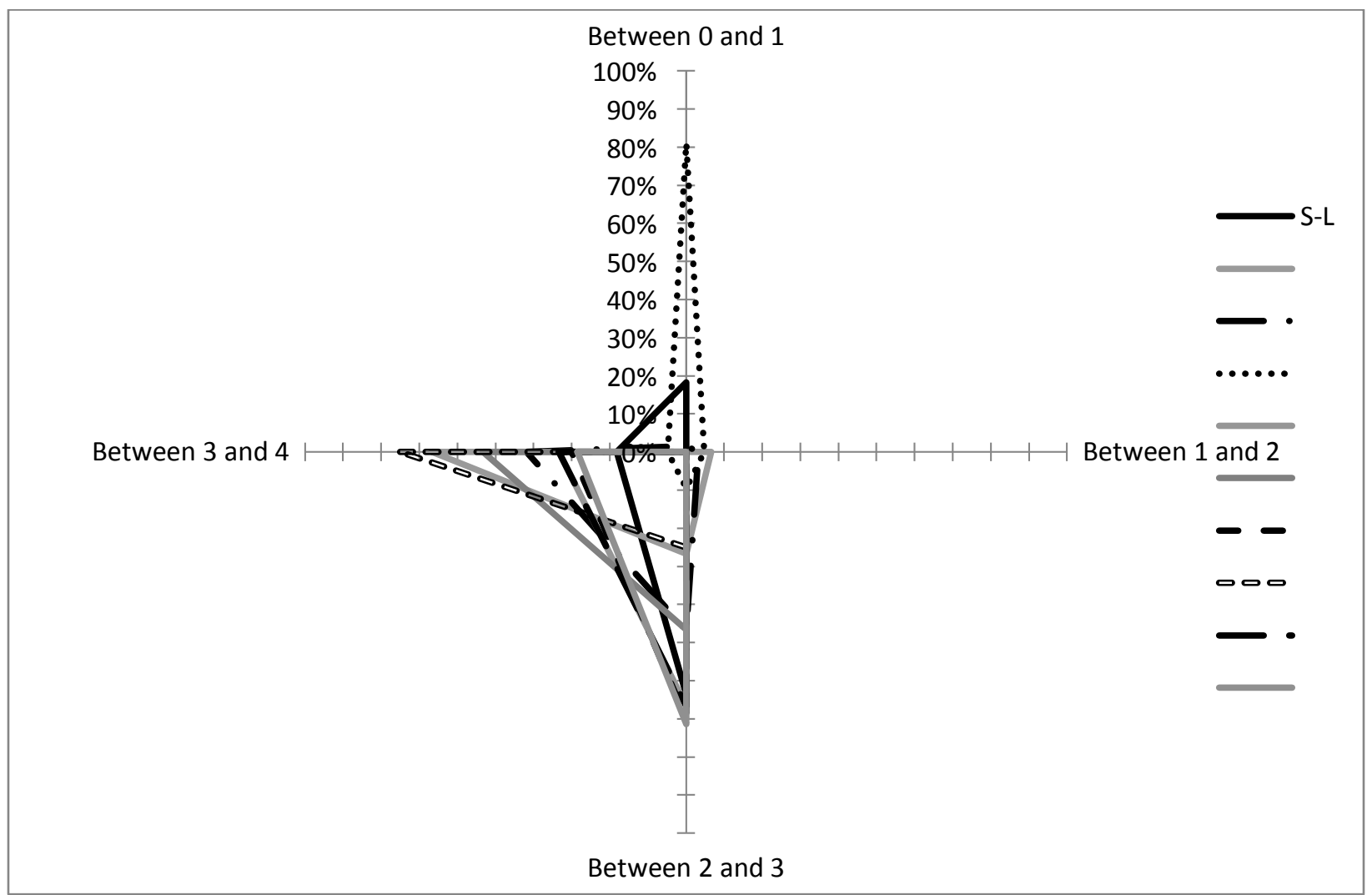

Figure 5. Fall 2010 Industrial Engineering Courses Showing the Proportion of Engineering Students by Frequency of Cumulative Grade Point Average (in four ranges) 
Ergonomics Service Learning Project: Implementing an Alternative Educational Method in an Industrial Engineering Undergraduate Ergonomics Course

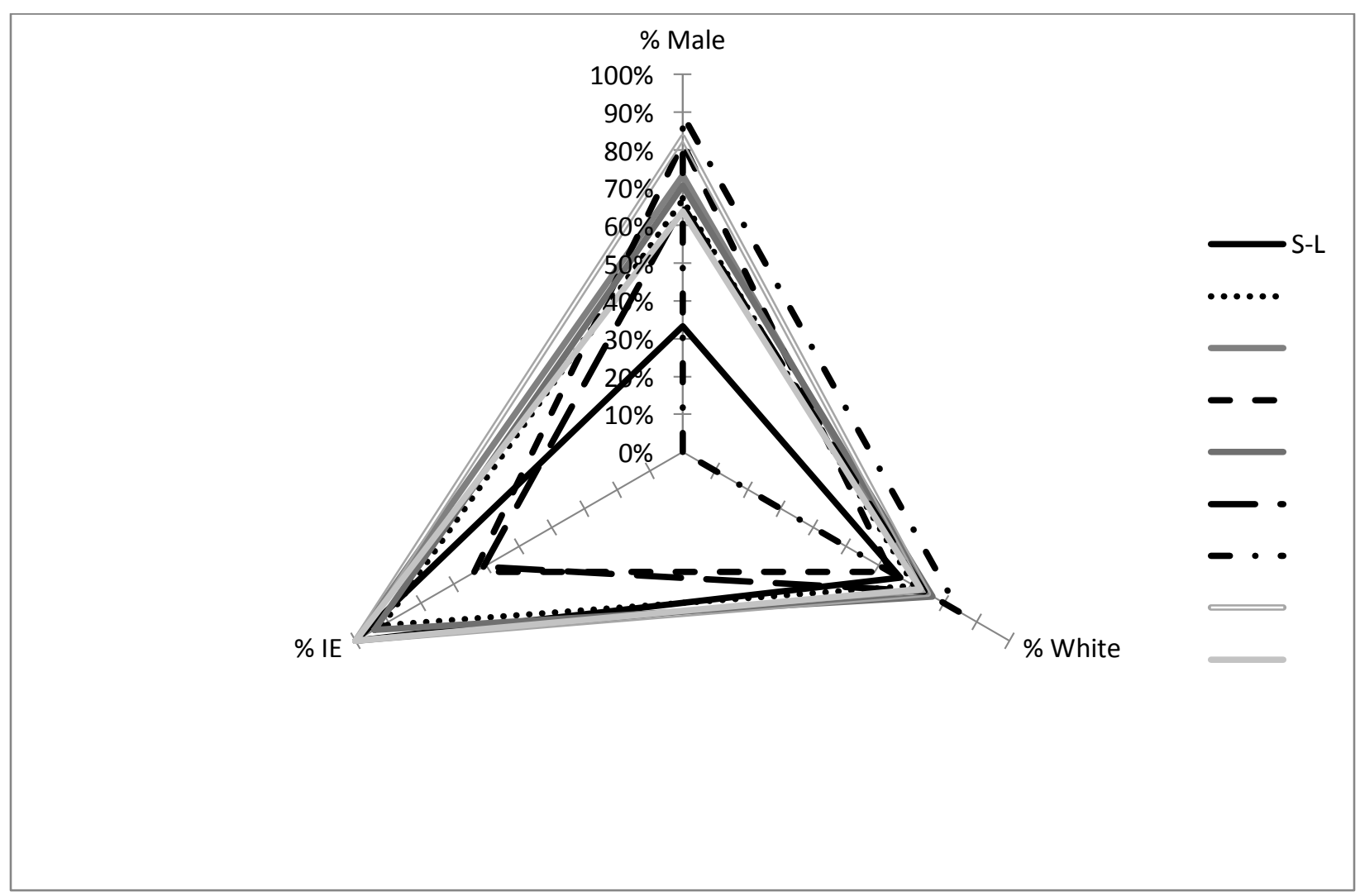

Figure 6. Fall 2011 Industrial Engineering Courses Showing the Proportion of Engineering Students in Each Course by Sex, Ethnicity and Engineering Major 
Ergonomics Service Learning Project: Implementing an Alternative Educational Method in an Industrial Engineering Undergraduate Ergonomics Course

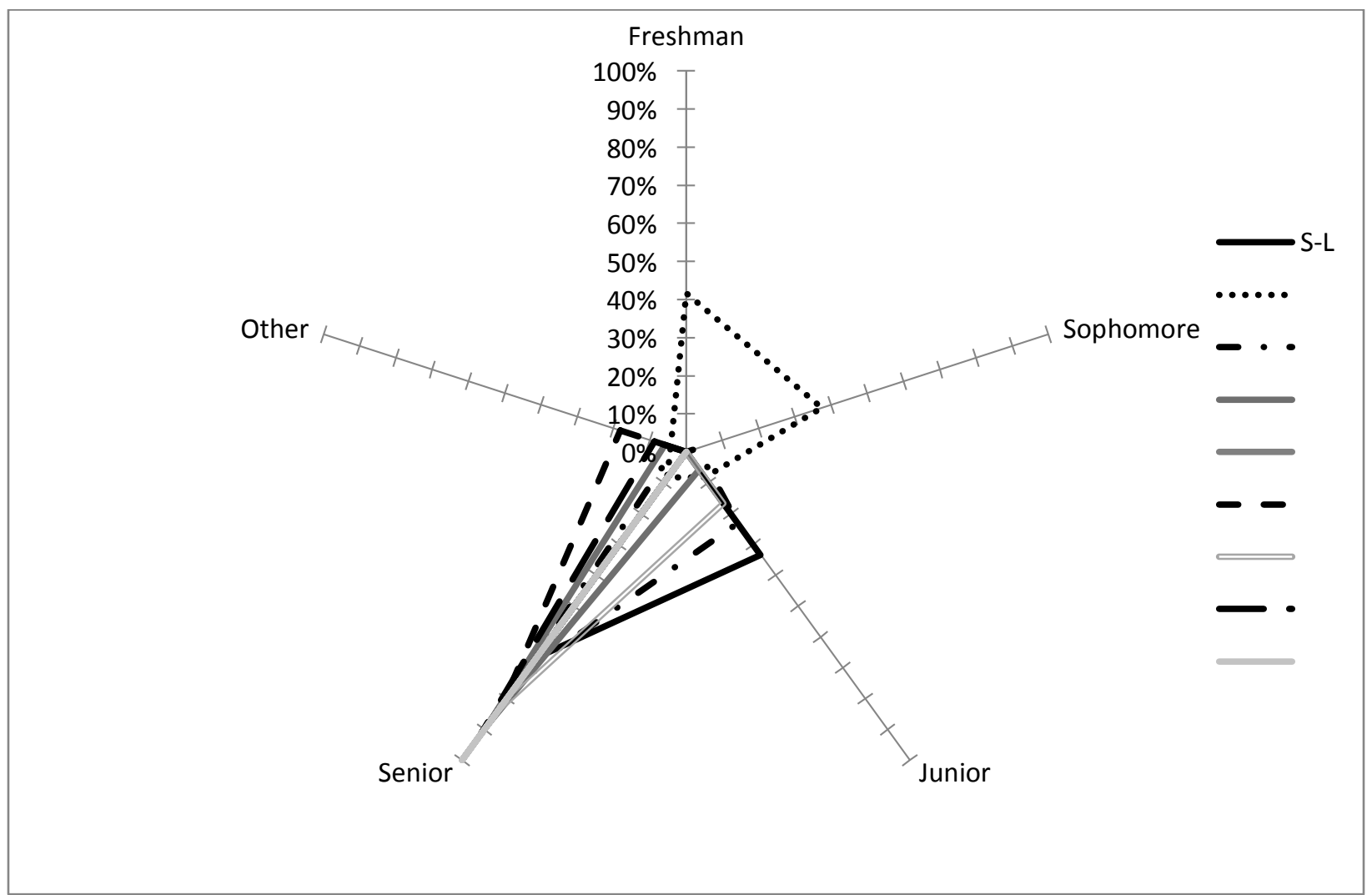

Figure 7. Fall 2011 Industrial Engineering Courses Showing the Proportion of Engineering Students in Each Course by Freshman, Sophomore, Junior, Senior and Other (Graduate or Post-Baccalaureate) 
Ergonomics Service Learning Project: Implementing an Alternative Educational Method in an Industrial Engineering Undergraduate Ergonomics Course

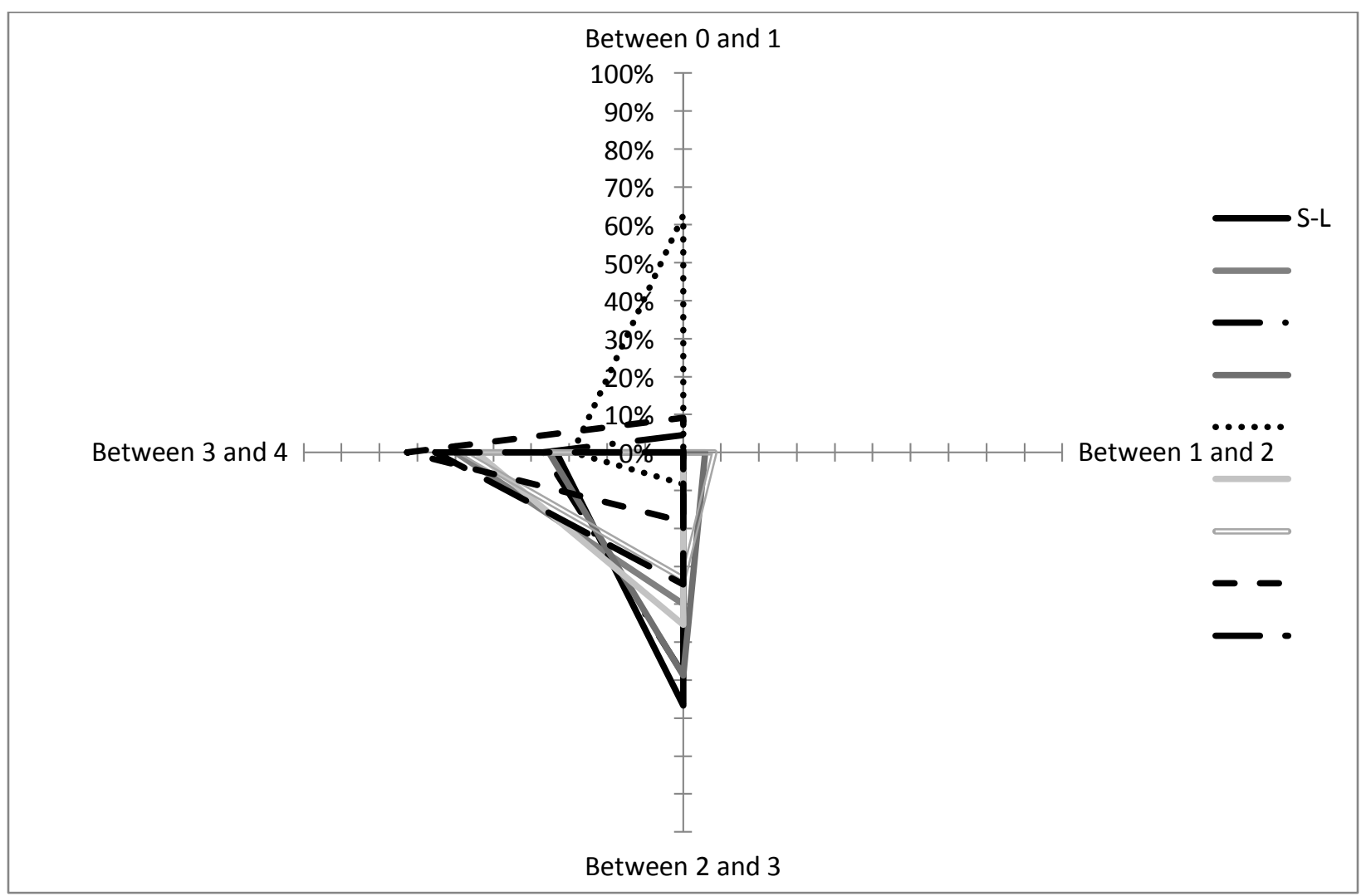

Figure 8. Fall 2011 Industrial Engineering Courses Showing the Proportion of Engineering Students by Frequency of Cumulative Grade Point Average (in four ranges) 